\title{
ORO TARŠOS KIETOSIOMIS DALELĖMIS RYŠYS SU VAIKŲ BRONCHŲ ASTMA: SISTEMINĖ APŽVALGA
}

\author{
Viktorija Šutova ${ }^{1}$, Nina Prokopčiuk ${ }^{1}$ Izabelẻ Juškienè ${ }^{1}$, Algirdas Valiulis ${ }^{2}$, \\ Edita Poluzioroviené ${ }^{1}$, Vaidotas Valskys ${ }^{3}$, Adomas Janulionis ${ }^{1}$, Vaida Taminskien $\dot{e}^{2}$, \\ Rimantas Stukas², Tomas Jankūnas ${ }^{4}$, Violeta Kvedariené ${ }^{1,5}$, \\ Narimantas Markevičius ${ }^{6}$, Arūnas Valiulis ${ }^{1,2,6}$ \\ ${ }^{1}$ Vilniaus universiteto medicinos fakulteto Klinikines medicinos institutas, ${ }^{2}$ Vilniaus universiteto \\ medicinos fakulteto Sveikatos mokslu institutas, ${ }^{3}$ Vilniaus universiteto Gyvybès moksly centro \\ Biomokslu institutas, ${ }^{4}$ Vilniaus Antakalnio progimnazija, ${ }^{5}$ Vilniaus universiteto Medicinos fakulteto \\ Biomedicinos mokslu institutas, ${ }^{6}$ Vilniaus miesto klinikine ligonine
}

Raktažodžiai: oro kokybė, oro tarša, kietosios dalelès, respiracinès alergozès, bronchų astma, sisteminè apžvalga, vaikai.

\footnotetext{
Santrauka

Apžvalginiame straipsnyje pateikiami susisteminti duomenys apie 2010-2020 m. publikacijas, skirtas oro taršos kietujų dalelių (KD) sąsajoms su vaikų bronchų astma. Daugelis analizuojamų publikacijų parengtos retrospektyvinių tyrimų pagrindu ir aptaria trumpalaikị kietųu dalelių poveikį, todèl ilgalaikès ekspozicijos reikšmè vaikams lieka nepakankamai ištirta. Daugiausia prieštaringų rezultatų siejama su itin smulkiu $(<0.1 \mu \mathrm{m})$ dalelių skaitinès koncentracijos tyrimais. Rasta pakankamai tyrimų, pagrindžiančių ryšị tarp oro taršos $\mathrm{KD}_{2.5}, \mathrm{KD}_{10}$, o ypač $\mathrm{KD}_{1}$ masès koncentracijos sergamumo bronchų astma. Vertinant šių dalelių integralių spektrų įtaką kvèpavimo sistemai, didžiausią reikšmę vaikų astmos atsiradimui ir eigai galètų turèti $0,1-1 \mu \mathrm{m}$ akumuliacinès modos dalelès, tačiau šiuo metu dar nèra tai pagrindžiančių tyrimų. Šios modos dalelių gyvavimas atmosferoje ilgiausias, sausas nusėdimas minimalus, o jų skaitinè ir masės koncentracijos bei kenksmingų medžiagų kiekiai yra santykinai dideli, todèl būsimi aerozolinès taršos ir respiracinių alergozių priežastinių ryšių tyrimai turètų susitelkti ị skaitinès ir masès koncentracijų submikroninių dalelių spektrus bei tikètinai taršai imliausius vyresnio ikimokyklinio ir jaunesnio mokyklinio amžiaus vaikus.

Santrumpos

CI - (angl. Confidence Interval) pasikliautinasis intervalas, HR - (angl. Hazard Ratio) rizikos santykis,
}

\begin{abstract}
$\mathrm{KD}_{0,3-1}-$ kietosios dalelès, kurių dydis yra intervale tarp 0,3 ir $1 \mathrm{mi}-$ krometro,

$\mathrm{KD}_{1}$ - kietosios dalelès, kurių dydis iki 1 mikrometro, $\mathrm{KD}_{10}$ - kietosios dalelès, kurių dydis iki 10 mikrometrų, $\mathrm{KD}_{2,5}$ - kietosios dalelès, kurių dydis iki 2,5 mikrometro,

$\mathrm{KD}_{2,5-10}$ - kietosios dalelès, kurių dydis yra intervale tarp 2,5 ir 10 mikrometru,

LUR - (angl. Land Use Regression) žemès naudojimo regresijos modelis,

NCD - (angl. Non-communicable Diseases) lètinès neinfekcinès ligos, OR - (angl. Odds Ratio) šansų santykis,

PMC - (angl. Particle Mass Concentration) dalelių masès koncentracija, PNC - (angl. Particle Number Concentration) dalelių skaitinè koncentracija,

PRISMA - (angl. Preferred Reporting Items for Systematic Reviews and Meta-Analyses) tyrimų atrankos schema sisteminėms apžvalgoms ir metaanalizèms,

UFP - (angl. Ultrafine Particles) itin smulkios kietosios dalelès.
\end{abstract}

\section{Ivadas}

Oro tarša - kasmet didèjanti, gyventojų sveikatai grèsminga problema. Kietosios dalelès (KD) - tai nevienalytis ore esančių dalelių ir skysčio lašelių (aerozolių) mišinys, kurio sudètyje gali būti įvairių komponentų - rūgštys, sulfatai, nitratai, organiniai junginiai, metalai, dirvožemio dalelès, dulkès, suodžiai ir kt. İ orą išmetamos kietosios dalelès labai skiriasi savo chemine sudètimi, fizinèmis charakteristikomis. Dalelių dydžiai (aerodinaminis skersmuo), išmetimo šaltiniai bei toksiškumas yra skirtingi.

Pagrindiniai KD šaltiniai miestuose - kelių transportas ir iškastinio kuro deginimas elektrinèse bei gamyklose. Didžiausias atskiras kietujų dalelių šaltinis yra motorinès dyzelinès transporto priemonès. KD yra tiesiogiai skleidžiamos šaltinio (pirminès), arba susidaro dèl atmosferoje 
vykstančių cheminių reakcijų bei kondensacijos (antrinès). KD pokyčiai aplinkoje ir žmogaus organizme bei poveikis mūsų kvėpavimo sistemai priklauso nuo dalelių dydžio, kuris varijuoja nuo kelių nanometrų iki mikrometrų [1]. Stambesnès dalelès nusèda trachejoje ir stambiuosiuose bronchuose, o smulkesnès gali skverbtis iki apatinių kvėpavimo takų ir kauptis plaučių regionuose, kur vyksta dujų apykaita. Pačios smulkiausios dalelès patenka ir ị kraujotaką [2]. $\mathrm{KD}_{10}$ dalelès, kurių dydis ore yra mažesnis nei $10 \mu \mathrm{m}$, ir $\mathrm{KD}_{2,5}$ dalelès, kurių dydis yra mažesnis nei $2,5 \mu \mathrm{m}$, patenka į orą iš dviejų pagrindinių šaltinių: deginant kurą bei tarpusavyje sąveikaujant kitiems teršalams. Epidemiologiniai duomenys rodo neigiamus sveikatos pokyčius tiek dèl trumpalaikio (24 val.), tiek dèl ilgalaikio (metinio) KD poveikio [3]. Dèl savo smulkumo jos ypač lengvai patenka ị kvèpavimo takus, sukeldamos širdies ir kvejpavimo sistemos ligas arba sunkindamos jų simptomus, todèl leistinas dalelių kiekis ore yra reguliuojamas Europos Sajungos ir atskirų valstybių istatymais.

Pastaraisiais dešimtmečiais visame pasaulyje stebimas išaugęs alerginių ligų, ypač atopinio dermatito, bronchų astmos ir alerginio rinito dažnis, kurio negalima paaiškinti tik genetiniais veiksniais. Vakarų Europos šalyse sergamumo rodikliai šiomis ligomis pastarajị dešimtmetị nedidejjo, o Rytų Europoje vaikų sergamumas respiracinèmis alergozèmis vis dar auga. Manoma, kad tam įtakos turi sparti vidinè migracija i didmiesčius, senų automobilių parko didejimas ir taršios pramonès plètra. Ilgalaikị oro taršos poveikị bronchų astmos išsivystymui buvo bandoma sistematizuoti suaugusiujų populiacijoje, gauti rezultatai yra prieštaringi [5-8]. Higienos instituto $2019 \mathrm{~m}$. duomenimis, Lietuvoje ligotumas astma per dešimtmetị išaugo daugiau nei du kartus. Daugiau nei pusę sergančiujų sudaro vaikai, didžiausias ligotumas ir astma sergančio vaiko šeimos gyvenimo kokybès prastejjimas fiksuojamas 5-9 metų grupejje $[4,49,50]$. Pradinukai didžiają laiko dali praleidžia ugdymo ịstaigoje, ịprastai vienoje klasèje, todèl svarbu išmatuoti oro taršą mokyklose. Tokio pobūdžio tyrimų yra nedaug, dažniausiai jie orientuoti ị $\mathrm{KD}_{2,5}$ bei $\mathrm{KD}_{10}$ masès koncentracijos vertinimą [43]. Tik keliuose jų vienu metu vertinta aerozolio dalelių skaitinè ir masès koncentracija patalpose ir mokyklą supančioje aplinkoje. Toks tyrimas buvo mūsų atliktas Vilniaus mokyklose [39, 40]. 2017-2018 m. oro taršos matavimai 11 Vilniaus mokyklu parode stiprią koreliaciją tarp dalelių skaitinès koncentracijos $\mathrm{KD}_{(0,3-1)}$ ir 6-11 metų moksleivių bronchų astmos paūmèjimo dažnio [47]. Nors akumuliacinès modos aerozolio daleliu $(0,1-1 \mu \mathrm{m})$ gyvavimo trukmè atmosferoje gana ilga (1-3 savaitès) [44-46], o jų masè, ypač dèl kumuliacijos proceso, pakankamai didele, šios KD frakcijos įtaka vaikų kvėpavimo sistemai dar mažai ištirta [48].
Tyrimo tikslas - sistemiškai ịvertinti per pastaruosius dešimt metų publikuotus epidemiologinius, kohortinio stebejjimo ir eksperimentinius tyrimus, kuriuose buvo nagrinèjamas ryšys tarp oro taršos kietosiomis dalelèmis ir vaiku bronchų astmos, vertinant etiologiniu ir ligos kontrolès požiūriais.

\section{Tyrimo objektas ir metodai}

Tyrimo objektas - mokslinėse duomenų bazèse esančios publikacijos lietuvių ir anglų kalbomis $(2010 \mathrm{~m}$. spalio 2020 m. spalio mèn. įskaitytinai), kuriose aptariamos oro taršos kietosiomis dalelèmis sąsajos su vaikų bronchų astmos atsiradimu arba eiga (sunkumas, paūmėjimų dažnis). Paieška buvo atliekama $2020 \mathrm{~m}$. rugsėjo - spalio mėnesiais 3 duomenų bazèse: MEDLINE (PubMed), Web of Science, Cohrane Library bei naudojantis Google Scholar paieškos sistema. Paieškai buvo naudojami šie raktiniai žpdžiai ir jų deriniai: "aerosol pollution" OR "aerosol emission" OR "particulate matter" OR "airborne aerosol" OR "aerosol particle number" OR "particle mass concentration" OR "indoor aerosol" OR "outdoor aerosol" OR "ultrafine matter" OR "fine matter" OR "coarse matter" OR "PMC" OR "PNC") AND ("childhood asthma" OR "pediatric asthma" OR "paediatric asthma" OR "allergic rhinitis" OR "respiratory allergies") AND ("prevalence" OR "morbidity" OR "risk" OR "incident" OR "development" OR "new onset") NOT "prenatal exposure" NOT "wheeze". Itraukti epidemiologiniai ir stebejjimo tyrimai (skerspjūvio, atvejo kontrolès, kohortos ). Buvo užpildyta tyrimų atrankos schema pagal PRISMA rekomendacijas. 29 publikacijos, skirtos vaiku bronchų astmai, ịtrauktos ị galutinę analizę.

\section{Tyrimo rezultatai}

Šioje analizèje apibendrinome tyrimus, kuriuose susirgimas bronchų astma apibréžiamas kaip naujas arba anksčiau diagnozuotas ligos atvejis. Dažniausiai oro taršos duomenys, naudojami epidemiologiniuose tyrimuose, gaunami iš oro taršos stebėsenos stočių, ekstrapoliuojant duomenis i vaiko gyvenamąą vietą, artimiausią vienai ar kitai matavimo stočiai $[18,22,56]$. Tik nedaugelyje tyrimų buvo taikomi matavimai vaikų namuose arba klasėse [36], keliuose tyrimuose atsižvelgta ị vaikų mobilumą [19, 20, 42]. Daugiau nei pusė tyrimų vertino KD poveiki pirmaisiais vaiko gyvenimo (gimimo) metais ir tik keli - efektą dèl kaupiamojo poveikio ir (ar) ekspoziciją skirtingais laikotarpiais. Nors ankstesnejje metaanalizèje (H. Khreis ir bendraaut., 2016) buvo nustatytas teigiamas, statistiškai reikšmingas ryšys tarp kelių oro teršalų ir naujų vaikų astmos atvejų, bendro rizikos įverčio negalima apibendrintai interpretuoti, kaip vien tik KD poveikio [5]. Išliko poreikis apibendrinti daugiau 
tyrimų, kuriuose būtų lyginamas efekto stiprumas skirtingu gyvenimo laikotarpiu, taikomas patobulintas ekspozicijos vertinimo būdas, pavyzdžiui, dispersijos modelis (ar ị jị panašus metodas), gebantis atskirti taršos šaltinį, naudojamas išsamesnis astmos apibrèžimas (ne tik tiriamujų ar jų tėvų pranešimai apie gydytojo diagnozę, bet ir registrų duomenys apie vaistų paskyrimus ir (ar) diagnozès kodai), sistemingai pranešama apie paklaidas, jos koreguojamos, sistemingai tiriami skirtumai tarp astmos fenotipų.

Nors kietosios dalelès dažniau, nei kiti teršalai, susijusios su neigiamu poveikiu sveikatai, nèra detalizuota, kokia būtent aerozolio spektro frakcija atsakinga už neigiamą poveikị vaikų kvėpavimo sistemai, kai vertinama ir dalelių skaitinè, ir masès koncentracija tuo pačiu metu. U. Franck ir bendraautorių (2011) tyrimas parodè, kad patalpų aerozolio dalelių poveikis vaikų sveikatai priklauso nuo dalelių dydžio, o tai sudètingesnis apibūdinimas, nei apytikslis $\mathrm{KD}_{10}, \mathrm{KD}_{2,5}$ ar UFP suskirstymas. Bronchito rizika siejama su patalpu $\mathrm{KD}_{1}(<1 \mu \mathrm{m}$ dalelių koncentracija): stipriausias poveikis pastebètas dalelių masès koncentracijai $<1 \mu \mathrm{m}$, ir dalelių skaitinei koncentracijai $>0,5 \mu \mathrm{m}$ [41]. Nepaisant pažangesnių prieinamų oro taršos matavimo metodų, duomenys apie KD vaidmenį vaikų respiracinių alergozių etiologijoje išlieka prieštaringi. Daugelyje kohortų pagrindinis KD šaltinis buvo su motoriniu transportu susijusi tarša (angl. traffic-related air pollution). Apžvelgus esamas publikacijas, statistiškai reikšmingos asociacijos tarp oro taršos kietosiomis dalelemis ir vaikų astmos išsivystymo daugiausia buvo stebimos Šiaurès Amerikos ir Europos gimimo kohortos tyrimuose, kai padidinta KD ekspozicija po gimimo buvo reikšmingai susijusi su didesne naujos astmos rizika darželinukams ar mokyklinio amžiaus vaikams. U. Gehring ir bendraautorių tyrime buvo nustatytas didesnis naujų astmos atvejų paplitimas iki $20 \mathrm{~m}$. amžiaus tarp tiriamujų, kurių aplinkoje po gimimo užfiksuota padidinta visų KD frakcijų ekspozicija [OR - Odds Ratio $\mathrm{KD}_{2,5} 1,15 / 1,2 \mu \mathrm{g} / \mathrm{m} 3$ (95\% CI - Confidence Interval 1,02$1,30) ; \mathrm{KD}_{10} 1,09 / 1,2 \mu \mathrm{g} / \mathrm{m} 3$ (95\% CI 1,01-1,18); $\mathrm{KD}_{2,5-10}$ $1,12 / 0,9 \mu \mathrm{g} / \mathrm{m} 3$ (95\% CI 1,04-1,20)]. Atlikus analizę pagal lyti, stipresnis ryšys buvo nustatytas mergaitems [12]. L. Tetreault ir bendraautorių tyrime astmos pradžia vaikams buvo susijusi su $\mathrm{KD}_{2,5}$ ekspozicija gimimo vietoje ir stebejjimo momentu po tam tikro laiko [HR - Hazard Ratio $1,30 / 6,50 \mu \mathrm{g} / \mathrm{m} 3(95 \%$ CI 1,28-1,32) ir $1,32 / 6,53 \mu \mathrm{g} / \mathrm{m} 3$ (95\% CI 1,31-1,33) atitinkamai] [13]. Kanados kohortos tyrimas $2010 \mathrm{~m}$. nustatẻ statistiškai reikšmingai padidèjusią astmos riziką dèl $\mathrm{KD}_{10}$ ekspozicijos pirmaisiais gyvenimo metais, apskaičiuotą pagal atvirkščiai proporcingo atstumo metodą (angl. Inverse-distance method): OR 1,07 / $1 \mu \mathrm{g} / \mathrm{m} 3$ $(95 \%$ CI 1,03-1,12) [14]. N. Kravitz-Wirtz ir bendraautorių dviejų JAV kohortų duomenimis, statistiškai reikšmingas ryšys [OR 1,25 / 4,43 $\mu / \mathrm{m} 3(95 \% \mathrm{CI} 1,06-1,46)]$ tarp $\mathrm{KD}_{2,5}$ poveikio ankstyvojoje vaikystejje ir vélesnès astmos rizikos buvo stebimas prieš ir po rezultatų koregavimo pagal kitus svarbius veiksnius (pvz. pasyvusis rūkymas namuose, šeimos pajamos) [15]. Atskiras tyrimų pluoštas galètų būti skirtas elektroninių cigarečių naudojimui [52].

A. Pennington ir bendraautoriai ištyrè, $\mathrm{kad} \mathrm{KD}_{2,5}$ (iš nepastovaus šaltinio) padidejimas 2,7 karto pirmaisiais gyvenimo metais, susijęs su absoliučiu astmos rizikos padidèjimu iki 5 metų amžiaus [HR 1,16 / logaritminiam augimui $\mu \mathrm{g} / \mathrm{m} 32,7$ karto $(95 \%$ CI 1,07-1,26)]. Atsakas stebimas žemesnèse ekspozicijos koncentracijose [16]. I apžvalgą įtraukème vienintelị tyrimą didelès rizikos kohortoje, kurio duomenimis, vaikams esant didelei astmos rizikai $\mathrm{KD}_{2,5}$ koncentracijos padidèjimas, net ir santykinai žemo lygio, susijęs su naujos bronchų astmos išsivystymu $[3,1 / 4,1$ $\mu \mathrm{g} / \mathrm{m} 3(95 \%$ CI 1,3-7,4)] [17]. Dviejose gimimo kohortose astma buvo suskirstyta ị atopinę ir neatopinę: Nyderlandų kohortoje $\mathrm{KD}_{2,5}$ poveikis po gimimo buvo susijęs su reikšmingu naujų astmos atvejų skaičiaus padidejjimu [OR 1,26 / $3,2 \mu \mathrm{g} / \mathrm{m} 3$ (95\% CI 1,04-1,51)] [18], švedų kohortoje $\mathrm{KD}_{10}$ ekspozicija kūdikystèje buvo susijusi su nealerginès astmos simptomų išsivystymu iki 8 metų amžiaus $[3,8 / 7,2 \mu \mathrm{g} /$ m3 (95\% CI 0,9-16,2)] [19]. Priešingai šiems rezultatams, dviejuose tyrimuose, apibendrinančiuose duomenis iš kelių Europos gimimo kohortu, reikšmingo ryšio nebuvo nustatyta $[20,21]$. Azijos šalyse rezultatai buvo labiau heterogeniški. Didelè dalis ten atliktų tyrimų - skerspjūvio, atvejo kontrolès arba tyrimai ne gimimo kohortose. Nors jau buvo atlikti keli prospektyviniai kohortos tyrimai, daug tyrimų, nagrinėjančių šią problemą, dar tebevyksta. 2019 m. Taivane atliktas tyrimas, įtraukiantis 184604 vaikus, kuris parodè, kad padidejusi $\mathrm{KD}_{2,5}$ ekspozicija 9-46 sav. po gimimo turi sąsają su didesne naujų astmos atvejų rizika vyresniame amžiuje. Šioje kohortoje vèliau atliktas skerspjūvio tyrimas ir nustatytas reikšmingas ryšys tarp $\mathrm{KD}_{2.5}$ ir vaikų astmos paplitimo [22]. F. Chen ir bendraautorių tyrime ikimokyklinio amžiaus vaikams šis ryšys išliko stiprus, neatsižvelgiant ị kitus individualius rizikos veiksnius [OR 1,07 / $10 \mu \mathrm{g} / \mathrm{m} 3$ (95\% CI 1,00-1,15)] [23]. Kitose Kinijos ir Pietų Korejos populiacijose ieškomų sąsajų nebuvo nustatyta, tačiau ịtakos baigtims galëjo turèti maža imtis, netinkamas poveikio klasifikavimas dèl vaikų mobilumo arba svarbių kintamųjų neįtraukimas (rūkymo, genetinio komponento) [24, 25].

Yra ịrodymų, kad bronchinès astmos diagnozès tikslumas gali skirtis priklausomai nuo vaiko amžiaus, o jaunesni vaikai gali išaugti astmos simptomus vyresniame amžiuje [5]. Ankstyvojo ikimokyklinio amžiaus vaikams sudètinga nustatyti astmos diagnozę dèl simptomų nespecifiškumo, todèl galima paklaida klasifikuojant baigtis. Dèl šios priežasties 
gali skirtis gimimo kohortose gauti rezultatai vaikams iki 4 metų. U. Gehring ir bendraautorių duomenys iš keturių gimimo kohortų patvirtina, kad oro tarša kietosiomis dalelèmis ankstyvame amžiuje gali prisidèti prie astmos vystymosi vaikysteje ir paauglysteje, ypač po 4 metų amžiaus, kai galima patikimiau diagnozuoti šią ligą, o oro taršos mažinimas galètu padèti užkirsti kelią vaikų astmos atsiradimui [26].

Dalyje ị apžvalgą įtrauktų tyrimų be naujų atvejų rizikos buvo tiriamas KD poveikis vaikų astmos paūmejjimu ir hospitalizacijų dèl šios ligos dažniui. KD poveikio rizika jau esamos astmos simptomams yra pakankamai gerai ištirta keliose metaanalizèse ir sisteminėse apžvalgose, tokių tyrimu yra daug. $2016 \mathrm{~m}$. H. Lim ir bendraautoriai apibendrino, kad esant trumpalaikei ekspozicijai, kietujų dalelių koncentracijai padidejus $10 \mu \mathrm{g} / \mathrm{m} 3$, vaiko hospitalizacijos ar apsilankymo prièmimo skyriuje dèl astmos rizika išauga 4,8 procento. Jei atsižvelgsime i tai, kad oro tarša paveikia platų regionų spektrą ir daug populiacijų, šis skaičius nèra nereikšmingas. Esminis sprendimas yra kietujų dalelių išmetimo šaltinių eliminavimas, todèl svarbu atlikti $\mathrm{KD}_{2.5}$ šaltinių tyrimus ir parengti aplinką tausojančią politiką [27, 51].

Atskiras tyrimų pluoštas yra itin smulkios kietosios dalelès (angl. UFP - Ultrafine Particles, $<0,1 \mu \mathrm{m}$ ) ir jų poveikis vaikų kvėpavimo sistemai. Gauti rezultatai yra prieštaringi: vienuose tyrimuose įrodyta UFP sąsaja su kvėpavimo sistemos ligomis, kituose tokio ryšio nenustatyta. Beveik visuose tyrimuose, vertinančiuose itin smulkiu dalelių ekspoziciją, matuojama skaitinè dalelių koncentracija (angl. particle number concentration - PNC), išreikšta dalelių skaičiumi $/ \mathrm{cm}^{3}$ [28]. Taivane atliktame tyrime buvo stebimas reikšmingas atvirkštinis ryšys tarp spirometrinių plaučių funkcijos rodiklių ir antrinès skaitinès itin smulkių dalelių koncentracijos miesto ore. Be to, nustatyta, kad poveikiai kvèpavimo sistemai gali skirtis priklausomai nuo KD šaltinio [29]. UFP (skaitinè dalelių koncentracija) buvo išmatuota 25 mokyklose, Australijoje, tarša buvo sumodeliuota vaikų gyvenamosiose vietose, naudojant LUR (angl. Land Use Regression) modeli. Asociacijų su spirometrine plaučiu funkcija, kvépavimo takų simptomais ar astmos diagnoze nebuvo nustatyta, tačiau buvo keletas irodymų, kad alergiški asmenys labiau jautrūs itin smulkių dalelių ekspozicijai, jiems labiau būdingas pasikartojantis švokštimas bei kosulys [30]. A. Paunescu ir bendraautoriai taip pat nerado sąsajos tarp itin smulkių KD ir plaučių funkcijos parametrų mokyklinio amžiaus vaikams [31]. Sąsajos nenustatyta ir patalpų oro taršai itin smulkiomis dalelėmis [32]. H. Wood ir bendraautoriai nustate teigiamas sąsajas su alerginiu rinitu, bet ne su bronchine astma [53]. Daugiausiai įrodymų apibendrinta 2019-2020 m. naujausiose metaanalizèse šia tema: apskaičiavus šansų santykius, teigiamas ryšys buvo stebimas tarp UFP ir vaikų astmos paūmèjimų, su astma susijusių apsilankymų priemimo skyriuje ir hospitalizacijų; stipriausias ryšys nustatytas praejjus ilgam laiko tarpui tarp ekspozicijos ir astmos paūmèjimo [33]. Kitoje metaanalizèje nuoseklus, statistiškai reikšmingas ryšys nustatytas šiltuoju sezonu ir miestuose, kur vidutinė dienos UFP koncentracija buvo $<6000$ dalelių $/ \mathrm{cm}^{3}$, o tai - apytikslè miestams būdinga KD skaičiaus mediana. 0-14 m. vaikams KD skaičiaus padidejjimas $10000 / \mathrm{cm}^{3} 2-3$ dieną iki matavimo buvo susijęs su reliatyvia hospitalizacijos dẻl kvẻpavimo ligų rizika [34]. Daugiau tyrimų reikia atlikti šalyse su didejjančia urbanizacija. Didejančios visuomenés sveikatos problemos, kurias sukelia lètinès neinfekcinès ligos (ang1. Non-communicable Diseases), miesto aplinkoje negali būti išspręstos vien sveikatos priežiūra - tarpdisciplininis požiūris yra privalomas [54].

Dauguma miesto gyventojų per 80 proc. savo kasdienio gyvenimo praleidžia patalpose. Patalpų $\mathrm{KD}_{2,5}$ koncentracija koreliuoja su aplinkos $\mathrm{KD}_{2,5}$ tarša daugelyje tyrimų. Sąryšis tarp patalpų KD taršos ir vaikų astmos simptomų panašus i lauko taršos [35]. Minètu laikotarpiu radome tik vieną tyrimą, kuriame atsispindètų patalpų oro taršos įtaka vaikų astmos incidentumui. C. Huang ir bendraautorių tyrime vidaus oro taršos, išmatuotos aerozolių masès monitoriumi, ryšys su vaikų astma pasižymėjo sezoniškumu. Pavasarị, vasarą ir rudenị bet kokios KD frakcijos asociacijos su bronchine astma buvo neigiamos, o žiemą $\mathrm{KD}_{2,5}, \mathrm{KD}_{4.0}, \mathrm{KD}_{10}$ vaikų miegamajame buvo iš dalies susijusios su vaikų astma [36].

Ši publikacijų, skirtų oro taršai ir žmonių kvẻpavimo sistemos ligoms, apžvalga turi keletą ribotumų. Daugelis apibendrinamų publikacijų paruoštos retrospektyvinių tyrimų pagrindu ir aptaria trumpalaikị kietujų dalelių poveikị, o ilgalaikès ekspozicijos reikšmè lieka nepakankamai ištirta. Daugeliu atvejų oro taršos poveikio tyrimai buvo statiniai, jie nekartoti vaikui augant, nèra lygintas taršos poveikis skirtinguose vaisiaus, kūdikio ir vaiko kvèpavimo sistemos vystymosi etapuose. Negalima nustatyti vienareikšmio UFP dalelių poveikio sveikatai, nes rezultatai prieštaringi. Yra nemažai tyrimų, įrodžiusių teigiamas $\mathrm{KD}_{2.5}, \mathrm{KD}_{10}$ ir $\mathrm{KD}_{1}$ masès koncentracijos koreliacijas su astma. Vertinant šių dalelių integralių spektru įtaką kvėpavimo sistemai, galime daryti prielaidą, kad didžiausią poveikị astmai gali turèti $0,1-1 \mu \mathrm{m}$ akumuliacinès modos dalelès. Šios modos dalelių gyvavimas atmosferoje pakankamai ilgas (1-3 savaitès), skaitinès ir masės koncentracijos gana didelès o kenksmingu medžiagų santykinai daug, lyginant su dalelių dydžiu, todèl akumuliacinès modos dalelių poveikis vaiko kvėpavimo takams turètų tapti pagrindiniu oro taršos poveikio vaiko sveikatai tyrimo objektu. 


\section{Išvados}

1.Aplinkos oro tarša yra savarankiškas vaikų kvėpavimo ligas sukeliantis ir jų eigą modifikuojantis veiksnys.

2. Aplinkos tarša kietosiomis dalelėmis didina bronchų astmos išsivystymo riziką, ypač genetinị polinkị sirgti šiomis ligomis turintiems vaikams.

3. Kietosios dalelès, veikdamos sinergiškai su oro alergenais, sunkina bronchų astmos eigą, blogina šios ligos kasdienę kontrolę ir didina apsilankymų gydymo įstaigoje dažnį.

4. Gyvenimas šalia judrių gatvių ir transporto keliama tarša reikšmingai prisideda prie naujų astmos atvejų atsiradimo, tačiau kitos kasdienès vaiko aplinkos, tokios kaip vaikų darželis, mokykla, oro taršos reikšmė bronchų astmos atsiradimui lieka neaiški.

5. Siekiant objektyviau įvertinti oro taršos kietosiomis dalelėmis reikšmę bronchų astmos etiopatogenezèje, tikslinga tirti atskiras kietujų dalelių spektro dalis, ypatingą dėmesị skiriant submikroninių dalelių skaitinei ir masès koncentracijoms.

\section{Literatūra}

1. Kelly FJ, Fussell JC. Size, source and chemical composition as determinants of toxicity attributable to ambient particulate matter. Atmospheric Environment 2012;60:504-26. https://doi.org/10.1016/j.atmosenv.2012.06.039

2. Oliveira M, Slezakova K, Delerue-Matos C, Pereira MC, Morais $\mathrm{S}$. Children environmental exposure to particulate matter and polycyclic aromatic hydrocarbons and biomonitoring in school environments: a review on indoor and outdoor exposure levels, major sources and health impacts. Environ Int 2019; 124:180-204.

https://doi.org/10.1016/j.envint.2018.12.052

3. Matuliauskaitė A. Particulate matter air pollution, its influence on life quality and the means of reducing indoor air pollution. Mokslas: Lietuvos ateitis, 2009;1(5).

4. Higienos institutas. Su klimato kaita susijusių alerginių ligų paplitimo $2018 \mathrm{~m}$. Lietuvoje apžvalga. Visuomenès sveikatos netolygumai, 2019; 4(37).

5. Khreis H, Kelly C, Tate J, Parslow R, Lucas K, Nieuwenhuijsen M. Exposure to traffic-related air pollution and risk of development of childhood asthma: a systematic review and meta-analysis. Environ Int 2017;100:1-31.

https://doi.org/10.1016/j.envint.2016.11.012

6. Anderson HR, Favarato G, Atkinson RW. Long-term exposure to air pollution and the incidence of asthma: meta-analysis of cohort studies. Air Qual Atmos Health 2013; 6(1):47-56. https://doi.org/10.1007/s11869-011-0144-5

7. Anderson HR, Favarato G, Atkinson RW. Long-term exposure to outdoor air pollution and the prevalence of asthma: metaanalysis of multi-community prevalence studies. Air Qual Atmos Health 2013; 6:57-68. https://doi.org/10.1007/s11869-011-0145-4
8. Gowers AM, Cullinan P, Ayres JG, Anderson HR, Strachan DP, Holgate ST, et al. Does outdoor air pollution induce new cases of asthma? Biological plausibility and evidence; a review. Respirology 2012; 17(6):887-98.

https://doi.org/10.1111/j.1440-1843.2012.02195.x

9. Weinmayr G, Romeo E, De Sario M, Weiland SK, Forastiere F. Short-term effects of PM10 and NO2 on respiratory health among children with asthma or asthma-like symptoms: a systematic review and meta-analysis. Environ Health Perspect 2010; 118(4):449-57.

https://doi.org/10.1289/ehp.0900844

10. Gehring U, Beelen R, Eeftens M, Hoek G, de Hoogh K, de Jongste JC, et al. Particulate matter composition and respiratory health: the PIAMA birth cohort study. Epidemiology 2015; 26(3):300-309.

https://doi.org/10.1097/EDE.0000000000000264

11. Yang A, Janssen NAH, Brunekreef B, Cassee FR, Hoek G, Gehring U. Children's respiratory health and oxidative potential of PM2.5: the PIAMA birth cohort study. Occup Environ Med 2016; 73(3):154-60. https://doi.org/10.1136/oemed-2015-103175

12. Gehring U, Wijga AH, Koppelman GH, Vonk JM, Smit HA, Brunekreef B. Air pollution and the development of asthma from birth until young adulthood. Eur Resp J 2020; 56(1):2000147. https://doi.org/10.1183/13993003.00147-2020

13. Tetreault L-F, Doucet M, Gamache P, Fournier M, Brand A, Kosatsky T, et al. Childhood exposure to ambient air pollutants and the onset of asthma: an administrative cohort study in Quebec. Environ Health Perspect 2016;124(8):1276-82. https://doi.org/10.1289/ehp.1509838

14. Clark NA, Demers PA, Karr CJ, et al. Effect of early life exposure to air pollution on development of childhood asthma. Environmental Health Perspectives 2010;118(2):284-90. https://doi.org/10.1289/ehp.0900916

15. Kravitz-Wirtz N, Teixeira S, Hajat A, Woo B, Crowder K, Takeuchi D. Early-life air pollution exposure, neighborhood poverty, and childhood asthma in the United States, 1990-2014. Int J Environ Res Public Health 2018;15(6):1114.

https://doi.org/10.3390/ijerph15061114

16. Pennington AF, Strickland MJ, Klein M, Zhai X, Bates JT, Drews-Botsch C, et al. Exposure to mobile source air pollution in early-life and childhood asthma incidence: the kaiser air pollution and pediatric asthma study. Epidemiology 2018;29(1):22-30. https://doi.org/10.1097/EDE.0000000000000754

17. Carlsten C, Dybuncio A, Becker A, Chan-Yeung M, Brauer M. Traffic-related air pollution and incident asthma in a high-risk birth cohort. Occup Environ Med 2011;68(4):291-5. https://doi.org/10.1136/oem.2010.055152

18. Gehring U, et al., 2010. Traffic-related air pollution and the development of asthma and allergies during the first 8 years of life. Am J Respir Crit Care Med 2010;181(6):596-603. 
https://doi.org/10.1164/rccm.200906-08580C

19. Gruzieva O, Bergström A, Hulchiy O, Kull I, Lind T, Melén E, et al. Exposure to air pollution from traffic and childhood asthma until 12 years of age. Epidemiology 2013; 24(1):54-61. https://doi.org/10.1097/EDE.0b013e318276c1ea

20. Mölter A, Simpson A, Berdel D, Brunekreef B, Custovic A, Cyrys J, et al. A multicentre study of air pollution exposure and childhood asthma prevalence: the ESCAPE project. Eur Respir J 2015; 45(3):610-24. https://doi.org/10.1183/09031936.00083614

21. Fuertes E, Sunyer J, Gehring U, Porta D, Forastiere F, Cesaroni $\mathrm{G}$, et al. Associations between air pollution and pediatric eczema, rhinoconjunctivitis and asthma: a meta-analysis of European birth cohorts. Environ Int 2020;136:105474.

https://doi.org/10.1016/j.envint.2020.105474

22. Chen B-Y, Chen C-H, Chuang Y-C, Wu Y-H, Pan S-C, Guo YL. Changes in the relationship between childhood asthma and ambient air pollution in Taiwan: results from a nationwide survey repeated 5 years apart. Pediatr Allergy Immunol 2019;30(2):188-94. https://doi.org/10.1111/pai.12999

23. Chen F, Lin Z, Chen R, Norback D, Liu C, Kan H, et al. The effects of PM2.5 on asthmatic and allergic diseases or symptoms in preschool children of six Chinese cities, based on China, Children, Homes and Health $(\mathrm{CCHH})$ project. Environmental Pollution 2018; 232:329-37.

https://doi.org/10.1016/j.envpol.2017.08.072

24. Min K-D, Yi S-J, Kim H-C, Leem J-H, Kwon H-J, Hong S, et al. Association between exposure to traffic-related air pollution and pediatric allergic diseases based on modeled air pollution concentrations and traffic measures in Seoul, Korea: a comparative analysis. Environ Health 2020;19(1):6. https://doi.org/10.1186/s12940-020-0563-6

25. Deng Q, Deng L, Lu C, Li Y, Norbäck D. Parental stress and air pollution increase childhood asthma in China. Environ Res 2018;165:23-31.

https://doi.org/10.1016/j.envres.2018.04.003

26. Gehring U, Wijga AH, Hoek G, Bellander T, Berdel D, Brüske I, et al. Exposure to air pollution and development of asthma and rhinoconjunctivitis throughout childhood and adolescence: a population-based birth cohort study. Lancet Respir Med 2015; 3(12):933-42.

https://doi.org/10.1016/S2213-2600(15)00426-9

27. Lim H, Kwon H-J, Lim J-A, Choi JH, Ha M, Hwang S-S, et al. Short-term effect of fine particulate matter on children's hospital admissions and emergency department visits for asthma: a systematic review and meta-analysis. J Prev Med Public Health 2016;49(4):205-19.

https://doi.org/10.3961/jpmph.16.037

28. Heinzerling A, Hsu J, Yip F. Respiratory health effects of ultrafine particles in children: a literature review. Water Air Soil Pollut 2016; 227.

https:/doi.org/10.1007/s11270-015-2726-6
29. Li Y-R, Feng L-T, Chen B-Y, Kim H, Yi S-M, Guo YL, et al. Association of urban particle numbers and sources with lung function among children with asthma or allergies. Sci Total Environ 2016;542(Pt A):841-4.

https://doi.org/10.1016/j.scitotenv.2015.10.098

30. Clifford S, Mazaheri M, Salimi F, Ezz WN, Yeganeh B, LowChoy S, et al. Effects of exposure to ambient ultrafine particles on respiratory health and systemic inflammation in children. Environ Int 2018;114:167-80.

https://doi.org/10.1016/j.envint.2018.02.019

31. Paunescu A-C, Casas M, Ferrero A, Pañella P, Bougas N, Beydon N, et al. Associations of black carbon with lung function and airway inflammation in schoolchildren. Environ Int 2019;131:104984. https://doi.org/10.1016/j.envint.2019.104984

32. Spickett J, Rumchev K, Jing H. The domestic environment and respiratory health of school children in Zongshan, China. Asia Pac J Public Health 2014; 26(6):596-603.

https://doi.org/10.1177/1010539512472944

33. Li Q, Yi Q, Tang L, Luo S, Tang Y, Zhang G, et al. Influence of ultrafine particles exposure on asthma exacerbation in children: a meta-analysis. Curr Drug Targets 2019;20(4):412-20. https://doi.org/10.2174/1389450119666180829114252

34. Samoli E, Rodopoulou S, Schneider A, Morawska L, Stafoggia M, Renzi M, et al. Meta-analysis on short-term exposure to ambient ultrafine particles and respiratory morbidity. Eur Respir Rev 2020; 29(158).

https://doi.org/10.1183/16000617.0116-2020

35. Sompornrattanaphan M, Thongngarm T, Tantilipikorn $P$, Kreetapirom P, Foo J. The contribution of outdoor fine particulate matter to indoor air quality in Bangkok Metropolitan Region, Thailand - are indoor dwellers safe? Siriraj Medical J 2018;70:265-71.

36. Huang C, Wang X, Liu W, Cai J, Shen L, Zou Z, et al. Household indoor air quality and its associations with childhood asthma in Shanghai, China: on-site inspected methods and preliminary results. Environmental Research 2016;151:154-67. https://doi.org/10.1016/j.envres.2016.07.036

37. Naclerio R, Ansotegui IJ, Bousquet J, Canonica GW, D'Amato $\mathrm{G}$, Rosario $\mathrm{N}$, et al. International expert consensus on the management of allergic rhinitis (AR) aggravated by air pollutants: impact of air pollution on patients with AR: current knowledge and future strategies. World Allergy Organ J 2020;13(3):100106. https://doi.org/10.1016/j.waojou.2020.100106

38. Li CH, Sayeau K, Ellis AK. Air pollution and allergic rhinitis: role in symptom exacerbation and strategies for management. J Asthma Allergy 2020;13:285-92. https://doi.org/10.2147/JAA.S237758

39. Prokopciuk N, Franck U, Dudoitis V, Tarasiuk N, Juskiene I, Valiulis A, et al. On the seasonal aerosol pollution levels and its sources in some primary schools in Vilnius, Lithuania. Environ Sci Pollut Res Int 2020; 27(13):15592-606. 
https://doi.org/10.1007/s11356-020-08093-9

40. Prokopciuk N, Franck U, Dudoitis V, Tarasiuk N, Juskiene I, Cepuraite D, Staras K, Valiulis A, Ulevicius V, Valiulis A. Global alliance against chronic respiratory diseases demonstration project: aerosol pollution and its seasonal peculiarities in primary schools of Vilnius. Chin Med J 2020;133:1516-1525. https://doi.org/10.1097/CM9.0000000000000913

41. Franck U, Herbarth O, Roder S, Schlink U, Borte M, Diez U, Kramer U, Lehmann I (2011) Respiratory effects of indoor particles in young children are size dependent. Sci Total Environ 409:1621-1631.

https://doi.org/10.1016/j.scitotenv.2011.01.001

42. McConnell R, Islam T, Shankardass K, Jerrett M, Lurmann F, Gilliland F, et al. Childhood incident asthma and traffic-related air pollution at home and school. Environmental Health Perspectives 2010;118(7):1021-6.

https://doi.org/10.1289/ehp.0901232

43. Eva C, Isabella A, Paolo C, Stylianos K, Joana M, Peter R, et al. SINPHONIE (Schools Indoor Pollution and Health Observatory Network in Europe): Executive Summary of the Final Report 2014.

44. Gieré R, Querol X. Solid particulate matter in the atmosphere. Elements 2010; 6(4):215-22.

https://doi.org/10.2113/gselements.6.4.215

45. Kwon H-S, Ryu MH, Carlsten C. Ultrafine particles: unique physicochemical properties relevant to health and disease. Exp Mol Med 2020;52(3):318-28. https://doi.org/10.1038/s12276-020-0405-1

46. Seinfeld JH, Pandis SN. Atmospheric chemistry and physics: from air pollution to climate change. John Wiley \& Sons 2016.

47. Prokopciuk N, Franck U, Valiulis A, Juskiene I, Dudoitis V, Tarasyuk N, Ulevicius V. Impact of indoor aerosol pollution at school on the incidence of respiratory morbidity among younger school age children [abstract]. In: The 8th Congress of the European Academy of Pediatric Societies - EAPS; 2020 Oct 16-20; Barcelona, Spain. Abstract 998.

48. Lippmann M, Chen LC, Gordon T, Ito K, Thurston GD. National Particle Component Toxicity (NPACT) Initiative: integrated epidemiologic and toxicologic studies of the health effects of particulate matter components [research report]. Europe PMC 2013; 177:5-13.

49. Taminskiene V, Alasevicius T, Valiulis A, Vaitkaitiene E, Stukas R, Hadjipanayis A, et al. Quality of life of the family of children with asthma is not related to asthma severity. Eur J Pediatr 2019;178:369-376.

https://doi.org/10.1007/s00431-018-3306-8

50. Taminskiene V, Vaitkaitiene E, Valiulis A, Turner S, Hadjipanayis A, Stukas R, Valiulis A. The self-reported quality of life of Lithuanian children with asthma was comparable to Western populations. Acta Paediatrica 2018;107(2):333-38.

https://doi.org/10.1111/apa.14140

51. Valiulis A, Bousquet J, Veryga A, Suprun U, Sergeenko S, Cebotari, et al. Vilnius declaration on chronic respiratory diseases: multisectoral care pathways embedding guided selfmanagement, health and air pollution in chronic respiratory diseases. Clin Transl Allergy 2019; 9:7.

https://doi.org/10.1186/s13601-019-0242-2

52. Bush A, Ferkol T, Valiulis A, Mazur A, Chkhaidze I, Maglakelidze T, Sargsyan S, Boyajyan G, Cirstea O, Doan S, Katilov O, Pokhylko V, Dubey L, Poluzioroviene E, Prokopciuk N, Taminskiene V, Valiulis A. Unfriendly fire: how the tobacco industry is destroying the future of our children. Acta Medica Lituanica 2021; 28 (1): 61-73.

https://doi.org/10.15388/Amed.2020.28.1.6

53. Wood HE, Marlin N, Mudway IS, Bremner SA, Cross L et al. Effects of air pollution and the introduction of the London low emission zone on the prevalence of respiratory and allergic symptoms in schoolchildren in east London: a sequential cross-sectional study. PloS One 2015;10(8).

https://doi.org/10.1371/journal.pone.0109121

54. Haahtela T, von Hertzen L, Anto JM, Bai C, Baigenzhin A, Bateman ED, et al. Helsinki by nature: the nature step to respiratory health. Clin Transl Allergy 2019;9.

https://doi.org/10.1186/s13601-019-0295-2

\section{COHESION OF PARTICULATE AIR POLLUTION AND BRONCHIAL ASTHMA IN CHILDREN: SYSTEMATIC LITERATURE REVIEW \\ V. Šutova, N. Prokopčiuk, I. Juškienė, A. Valiulis, E. Poluziorovienė, V. Valskys, A. Janulionis, V. Taminskienė, R. Stukas, T. Jankūnas, V. Kvedarienė, N. Markevičius, A. Valiulis}

Keywords: air quality, air pollution, particulate matter, respiratory allergoses, bronchial asthma, systemic review, children.

Summary

The review article presents data of systemic analysis of publications on particulate matter pollution and its links to bronchial asthma in children. It was analysed relevant publications from data bases of PubMed, Web of Science, Cohrane Library, Google Scholar for the period of October 2010 - October 2020. The most contradictory results are related to ultrafine $(<0.1 \mu \mathrm{m})$ particle number concentration. At the other hand it was documented association between $\mathrm{PM}_{2.5}, \mathrm{PM}_{10}, \mathrm{PM}_{1}$ mass concentrations and incidence as well as severity of asthma in children. It can be suggested that accumulation mode $(0.1-1 \mu \mathrm{m})$ particles may have the greatest influence on the etiopathogenesis of asthma in children. The lifetime of these particles in the atmosphere is rather long (few weeks) and dry deposition is minimal, particle number and mass concentrations as well as the amount of harmful substances are relatively high. Therefore, future studies on the causal relationship between aerosol contamination and bronchial asthma should focus on the spectra of number and mass concentrations of submicron $(<1 \mu \mathrm{m})$ particles as well as the most susceptible preschool and younger school age children.

Correspondence to: arunas.valiulis@mf.vu.lt

Gauta 2021-03-09 